\title{
FLUORIDE ALTERNATIVES FOR REMINERALIZATION OF EARLY ENAMEL CARIOUS LESIONS, FACT OR FICTION? - A SYSTEMATIC REVIEW
}

\author{
Nasr Mohamed Attia*, Mahmoud Mohammed Hasan ${ }^{* *}$ and Nadhem Mohammed Sallam***
}

\begin{abstract}
Aim: The purpose of this study was to systematically assess the quality of evidence supporting fluoride's alternatives for treating early enamel caries.

Methods: A broad search strategy using PubMed and other sources was performed. For sensitive search strategy, we used MESH database and the following search queries: ("Remineralization" [Mesh] OR "Remineralisation") AND ("Caries" [Mesh] OR "Decay") AND ("Fluoride"). Predetermined criteria were: parallel, randomized, controlled trial studies with 6 to 18 years old children.

Results: 1919 articles from PubMed advanced search were initially revealed then 79 papers were picked up, in addition to 536 from other sources. One paper only removed as a duplicate (by the author, title and reference). The remaining articles were indicated for closer assessment. Out of 614 papers were screened by title, only 29 met the inclusion criteria of this review. Additional screening by abstract was done independently by the three researchers to result in 7 articles.

Conclusion: From this review, there is moderate clinical evidence to support preventive agents as fluoride substitutes. This review suggests the use of resin infiltration and fluoridated Miswak as remineralizing agents.
\end{abstract}

KEYWORDS: Early enamel caries - Fluoride - Remineralizing agents.

\section{INTRODUCTION}

There is no doubt that the introduction of different remineralizing agents such as fluoride products has contributed to a significant decrease in the severity and prevalence of dental caries, particularly in developed countries. Despite this progress, dental caries remains the most common oral disease and a challenge for the dental team ${ }^{1}$.

According to the previous researches, Dental caries can be defined as a multifactorial disease results in the dissolution of dental hard tissues due to loss of minerals by substantial $\mathrm{pH}$ fluctuations by

\footnotetext{
* Lecturer, Department of Pedodontic, Dental Public Health and Preventive Dentistry. Faculty of Dentistry, Mansoura University. Egypt. **Assistant Lecturer of Pedodontic, Dental Public Health, and Preventive Dentistry. Faculty of Dentistry, Mansoura University. Egypt. *** Ph.D. in Pediatric Dentistry, Dental Public Health, and Preventive Dentistry. Faculty of Dentistry, Mansoura University. Egypt.
} 
cariogenic bacteria located in the dental biofilm ${ }^{2}$. Yet, the carious process alternates remineralization and demineralization cycles with reversible or irreversible stages ${ }^{3}$.

White spot lesions (WSL) are the first visual clinical observation of dental caries and may be either active (rough and opaque) or inactive (smooth and shiny) due to demineralization of the enamel subsurface, with increased porosity due to the removal of minerals from the deep tissue to the outside surface ${ }^{2}$. If de-mineralization remains untreated, however, dental caries can progress into irreversible stages of enamel breakdown and apparent cavitation ${ }^{1}$. Approaches to prevent or treat WSLs are of great importance, particularly in young ages ${ }^{4}$. Topical fluorides, including fluoride toothpaste, fluoride mouth rinses, and fluoride varnishes, are the most commonly used agents for treating WSLs ${ }^{5}$.

Many reports support that the preventive strategies, especially the use of fluorides, can arrest or even reverse the demineralization process of early enamel carious lesions. Moreover, the prevention of these lesions can be achieved in combination with other preventive measures such as dental biofilm control and diet control ${ }^{6}$. However, several researches have also investigated other remineralizing agents which could be valuable to control dental caries ${ }^{7}$.

On the other hand, concerns about exposure to fluoride from multiple sources are growing, potentially increasing their risk of developing dental fluorosis ${ }^{8}$. Another concern regarding fluoride therapy for the treatment of WSLs is the potential hyper-mineralization of the surface layer in the presence of high concentrations of fluoride ions which prevents the subsequent penetration of phosphate and calcium ions into the body of the lesion ${ }^{9}$. Nevertheless, a recent systematic review by Cochrane stated that the 6-week application of fluoride varnish was effective in preventing the formation of WSL. However, this approach is onerous, requires professional input and can be expensive ${ }^{10}$.

For ideal remineralization system, calcium, phosphate, and fluoride must all be available at sufficient levels in a bioavailable form in the oral environment to enhance the remineralizing ability of saliva and oral reservoirs without increasing the risk of calculus formation ${ }^{11}$. In recent years, the development of novel enamel remineralization systems has significantly progressed with many of them already in clinical use such as bioactive glass, casein phosphopeptide-amorphous calcium phosphate, self-assembling peptide, and resin infiltrate ${ }^{12}$.

The anti-caries benefits of calcium phosphatebased remineralization systems have been tested to remineralize WSL. Various randomized controlled clinical trials of post-orthodontic WSL demonstrated considerable results after the use of CPP-ACP preparations ${ }^{13-15}$. However, other studies could not prove any benefits of CPP-ACP-based remineralization products ${ }^{16,17}$.

Recently, various studies have shown the effectiveness of resin infiltrate in preventing further demineralization. This technique is based on a lowviscosity resin with a high penetration coefficient to prevent further progression of the lesion by sealing the enamel intercrystalline spaces ${ }^{18}$. An interesting addition to remineralizing agents is natural products such as:

G. Chinensis, grape seed extract and fluoride impregnated miswak that have demonstrated the ability to beneficially shift the de-/remineralization caries equilibrium 12, 19. However, chemical characterization and standardization of the natural products will be required before further application in clinical trials ${ }^{12}$.

There is a large amount of clinical evidence supporting the potential preventive effect of different fluoride formulations. However, the clinical evidence of the effectiveness of other remineralizing agents is far less convincing and lacking for head to head comparison. So, the aim of this systematic 
review is to answer the following question: "Do we have an effective preventive clinical intervention other than fluoride for early enamel caries?"

\section{METHODS}

For the preparation of this review, we followed the guidelines of the PRISMA statement.

\section{Literature search strategy}

A literature search through the computer, in all of PubMed, Springer, and Thomson Reuters, Thomson Reuters (conferences), Wiley, Nature, Science direct, and Scopus was performed to capture all the published studies. For the sensitive strategy of search, we employed the database of MESH and search queries as follows: ("Remineralization" [Mesh] OR "Remineralisation") AND ("Caries" [Mesh] OR "Decay")AND("Fluoride"). Screening the titles and abstracts of the retrieved articles were done by three authors. The screening for eligibility was completed in two steps. The first step involved screening abstracts for eligibility, and the second step involved retrieving and screening the full - text articles of eligible abstracts. A study was included in this review if, after discussion, at least two of the authors agreed that it was appropriate.

\section{Inclusion and exclusion criteria}

The criteria for inclusion used to filter the studies identified were:

- Participants: children of any gender with an age ranging from 6 to 18 years and have initial enamel carious lesions.

- Interventions: any remineralizing agent other than standard fluoride (with any form).

- Comparisons: standard fluoride or any other remineralizing agent if not found.

- Outcomes: Recognized clinical measures of early caries lesions or enamel demineralization.

- Study Design: Randomized parallel Clinical trials.
Whereas the exclusion criteria were:

- Reviews, case reports, abstracts, letters to editors, editorials, commentaries, in vitro and in situ studies utilizing bovine or human enamel were excluded.

- Non-English language studies were excluded.

- Studies utilizing an artificial caries model or enamel demineralization model were excluded.

- Studies contain placebo were excluded.

\section{Data extraction}

The data were extracted independently by three authors, using online data extraction form "Endnote". The data that extracted involved the following: (1) study design; (2) study population; (3) risk of bias domains; and (4) study outcomes. Disagreements were resolved by discussion between the three researchers.

\section{Quality assessment OR Risk of bias}

The quality of the recovered RCTs was assessed on the basis of the Cochrane Handbook for Systematic Intervention Reviews 5.1.0 (updated March 2011) using the quality assessment table contained in the same book (part 2, chapter 8.5) ${ }^{20}$. The Cochrane Bias Risk Assessment Tool included the following areas: sequence generation (selection bias), concealment of allocation sequence (selection bias), participants and personnel blinding (performance bias), blinding in outcome assessment (detection bias), and shortage in outcome data (attrition bias), selective reporting of outcomes (reporting bias) and other potential sources of bias. Authors 'final judgment was classified as low, high, or 'Unclear bias risk.'

\section{RESULTS}

A broad search through database was done by three researchers in 2-1-2019 that revealed initially a total of 1919 articles from PubMed advanced search which, after applying filters (randomized clinical 
trials - Humans- English - 6-18 years old) the results were 79 papers. A total of 536 from different sources (Springer 97, TR 100, TR conferences 97, Wiley 18, Nature 24, ScienceDirect 100 and Scopus 100).

A total of 615 articles were explored to the Endnote program. One paper only removed as a duplicate (by the author, title and reference) and the remaining articles were indicated for closer evaluation. These 614 papers were screened by title, most of these articles did not meet the inclusion criteria of this review. This filter reduced the articles to 29 that were screened by abstract independently by the three researchers and reduced to 7 articles.

The 22 papers were excluded due to either invitro, in-situ, including placebo or agents other than standard fluoride in control groups or the age of participants is out of age range included in this study. Finally, all the remaining seven studies were included in this review after full-text screening as in table 1 .

All the seven included studies are in vivo randomized clinical studies. Three studies 3,11,15 were conducted to evaluate the effect of CPP-ACP on WSLs in comparison with standard fluoridated toothpaste ${ }^{3,15}$ or with fluoride varnish ${ }^{11}$ in children and adolescents. Aykut et al. and Brochner et al. ${ }^{3,15}$ presented no clear significant differences between CPP-ACP and fluoride toothpaste in follow up endpoints. According to Brochneret al. ${ }^{15}$, both groups showed a significant reduction in measurements of WSLs after 4 weeks of follow up. Llena et al. 11 reported that CPP-ACP paste and CPP-ACP containing $900 \mathrm{ppm}$ fluoride both gave fewer scores of WSLs in comparison with professionally used 5 $\%$ sodium fluoride varnish after 8 and 12 months of follow up but without significant difference. The only significance between the groups, at a given time point, was that between Groups of CPP-ACP at four weeks.

Aykut et $\mathrm{al}^{3}$ showed that CPP-ACP presented a reduction in the scores of WSLs from baseline to 3 months of follow up but without significant difference while a group of fluoride paste only showed a significant increase in scores of WSLs after 3 months of follow up. Ferreira J.M.S. et al. ${ }^{6}$ compared the effect of two fluoride varnishes $(5 \% \mathrm{NaF}$ and $6 \% \mathrm{NaF}+6 \% \mathrm{CaF} 2$ ) in controlling carious development with WSLs. In their results, despite the mean value of the difference in reduction was higher in the group including $\mathrm{CaF} 2$ there was no significant difference presented between both fluoride varnish formulations. Almeida M.Q. et al. ${ }^{2}$ evaluated the therapeutic effect of FL- Fluorniz (5\% NaF); DUODuofluorid XII (6\% CaF2+6\% NaF); and DF- Durafluor $(5.5 \% \mathrm{NaF})$ in remineralization of WSLs and no significant difference was presented between the three fluoride varnish types regarding measurements through using a WHO periodontal probe.

Baeshen et al. ${ }^{19}$ add a $0.5 \%$ sodium fluoride to natural Miswak and compared it with natural Miswak without fluoride (used in one quadrant in comparison with the other quadrant that treated only by fluoridated toothpaste) for remineralization of WSLs. They showed in their results that fluoridated miswaks presented a significant reduction in scores of WSLs scored by Diagnodent and ICDAS II scoring system in comparison with fluoridated toothpaste in the contralateral quadrant while the non-fluoridated miswaks presented no difference.

Cifici et al. ${ }^{4}$ treated WSLs by resin infiltrate in comparison with fluoride varnish for 3 months of follow up and a significant decrease was evident in both groups. By comparing measurements after one, two and three months of follow up the difference were significant in resin infiltrate group and not significant in fluoride varnish group.

\section{Quality of included studies}

The included studies were of quality in the range from low to moderate as recommended by the assessment tool of the risk of bias of Cochrane. The quality assessment of domains was summarized in figure 1 . 
The evidence strength, of the group of studies included in this systematic review, is moreover weakened due to short observation periods (Five studies ${ }^{2,6,11,15,19}$ with duration shorter than 3 months, varying outcome measures (clinical indices $2,4,6,11,19$ laser and light-induced fluorescence ${ }^{3,4,15,19}$ ) and the small total number of participants (360 participants for all included studies).

TABLE (1) Summary of included studies

\begin{tabular}{|c|c|c|c|c|c|c|c|}
\hline$\sum_{i}^{2} \theta$ & $\begin{array}{l}\text { Type of } \\
\text { study } \\
\text { design }\end{array}$ & Objectives & $\begin{array}{c}\text { Study } \\
\text { population }\end{array}$ & $\begin{array}{c}\text { Comparison } \\
\text { groups } \\
\text { (follow up) }\end{array}$ & $\begin{array}{c}\text { Other } \\
\text { sources of } \\
\text { fluoride }\end{array}$ & $\begin{array}{l}\text { Primary outcome } \\
\text { (measurement) }\end{array}$ & $\begin{array}{l}\text { Results for primary } \\
\text { outcome }\end{array}$ \\
\hline 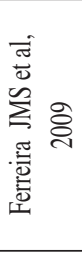 & $\mathrm{RCT}$ & $\begin{array}{c}\text { Preventive effect } \\
(5 \% \mathrm{NaF} \text { and } \\
6 \% \mathrm{NaF}+6 \% \\
\mathrm{CaF} 2) .\end{array}$ & $\begin{array}{l}15 \text { subjects } \\
\text { (7- to } \\
12 \text {-years) } \\
\text { with } \\
45 \text { active } \\
\text { WSLs }\end{array}$ & $\begin{array}{c}\text { At baseline } \\
\text { and after } 4 \\
\text { Weeks }\end{array}$ & $\begin{array}{c}\text { Fluoridated } \\
\text { toothpaste } \\
\text { and } \\
\text { prophylactic } \\
\text { paste }\end{array}$ & $\begin{array}{c}\text { Maximum WSL } \\
\text { dimensional changes } \\
\text { were measured and } \\
\text { lesion activity }\end{array}$ & $\begin{array}{c}\text { No statistically } \\
\text { significant } \\
\text { differences between } \\
\text { all groups }\end{array}$ \\
\hline 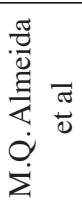 & $\mathrm{RCT}$ & $\begin{array}{c}\text { Preventive effect } \\
(5 \% \mathrm{NaF}, 6 \% \\
\mathrm{CaF} 2+6 \% \mathrm{NaF} \\
\text { and } 5.5 \% \mathrm{NaF})\end{array}$ & $\begin{array}{l}78(7-13 \\
\text { years) of } \\
67 \text { WSLs }\end{array}$ & $\begin{array}{c}\text { At baseline } \\
\text { and after } 5 \\
\text { weeks }\end{array}$ & $\begin{array}{c}\text { Dentifrice } \\
\text { of } 1500 \mathrm{ppm} \\
\text { fluoride }\end{array}$ & $\begin{array}{c}\text { Maximum WSL } \\
\text { dimensional changes } \\
\text { were measured and } \\
\text { lesion activity }\end{array}$ & $\begin{array}{c}\text { No statistically } \\
\text { significant } \\
\text { differences between } \\
\text { all groups }\end{array}$ \\
\hline 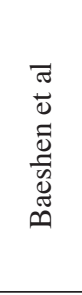 & RCT & $\begin{array}{l}\text { Therapeutic } \\
\text { effect of } \\
\text { fluoridated and } \\
\text { non-fluoridated } \\
\text { Miswak on } \\
\text { WSLs }\end{array}$ & $\begin{array}{c}19 \\
\text { orthodontic } \\
\text { patients } \\
\text { (mean age, } \\
17.2 \text { years) } \\
\text { with } 150 \\
\text { WSLs } \\
\end{array}$ & $\begin{array}{c}\text { At baseline } \\
\text { and } 2,4, \text { and } \\
6 \text { weeks }\end{array}$ & $\begin{array}{c}\text { Fluoridated } \\
\text { toothpaste } \\
(1450 \mathrm{ppm})\end{array}$ & $\begin{array}{l}\text { WSLs scored using } \\
\text { DIAGNOdent pen } \\
\text { and } \\
\text { ICDAS II index }\end{array}$ & $\begin{array}{c}\text { Statistically } \\
\text { significant } \\
\text { differences between } \\
\text { the } 2 \text { quadrants in the } \\
\text { test group but not in } \\
\text { the control group }\end{array}$ \\
\hline 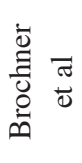 & RCT & $\begin{array}{l}\text { Therapeutic } \\
\text { effect of } 10 \% \\
\text { CPP-ACP on } \\
\text { WSLs }\end{array}$ & $\begin{array}{l}\text { Children } \\
(13-18 \\
\text { years) with } \\
327 \text { WSLs }\end{array}$ & $\begin{array}{c}\text { At baseline } \\
\text { and after } 4 \\
\text { weeks }\end{array}$ & $\begin{array}{c}\text { Water } \\
\text { fluoridation } \\
(<0.2 \mathrm{ppm} \mathrm{F})\end{array}$ & $\begin{array}{c}\text { Readings of } \\
\text { QLF and clinical } \\
\text { inspection of WSLs }\end{array}$ & $\begin{array}{c}\text { No statistically } \\
\text { significant } \\
\text { differences between } \\
\text { the groups }\end{array}$ \\
\hline $\begin{array}{l}\infty \\
\stackrel{\infty}{0} \\
N \\
N \\
\bar{U} \\
= \\
ن\end{array}$ & $\mathrm{RCT}$ & $\begin{array}{l}\text { Therapeutic } \\
\text { effect of resin } \\
\text { infiltrate or } \\
\text { fluoride varnish } \\
\text { on (WSLs) }\end{array}$ & $\begin{array}{c}132 \text { teeth } \\
\text { from } 68 \\
\text { patients ( } 8- \\
16 \text { years) } \\
\text { with WSLs }\end{array}$ & $\begin{array}{l}\text { Before, just } \\
\text { after the } \\
\text { application, } \\
\text { and after } 1 \\
\text { month and } \\
3 \text { months }\end{array}$ & $\begin{array}{l}\text { Toothpaste } \\
\text { with } 1,500 \\
\text { ppm fluoride }\end{array}$ & $\begin{array}{c}\text { Lesions were scored } \\
\text { with DIAGNOdent } \\
\text { and ICDAS II }\end{array}$ & $\begin{array}{c}\text { Statistically } \\
\text { significant } \\
\text { differences was } \\
\text { obvious in all groups }\end{array}$ \\
\hline 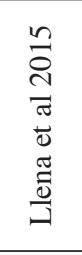 & $\mathrm{RCT}$ & $\begin{array}{c}\text { Therapeutic } \\
\text { effect of CCP- } \\
\text { ACP and CPP- } \\
\text { AC FP and 5\% } \\
\text { fluoride varnish } \\
\text { on WSLs }\end{array}$ & $\begin{array}{c}60 \text { children } \\
(6-14 \\
\text { years) with } \\
786 \\
\text { WSLs }\end{array}$ & $\begin{array}{c}\text { At baseline } \\
\text { and at } 4,8, \\
\text { and } 12 \text { weeks }\end{array}$ & $\begin{array}{c}\text { Fluoride } \\
\text { toothpaste } \\
\text { (1100 ppm } \\
\text { of fluoride) }\end{array}$ & $\begin{array}{l}\text { Lesions severity } \\
\text { scored using ICDAS } \\
\text { II and Diagnodent } \\
\text { also lesions activity } \\
\text { evaluated using the } \\
\text { Ekstrand criteria }\end{array}$ & $\begin{array}{c}\text { A significant } \\
\text { difference was clear } \\
\text { between groups at } \\
\text { different intervals }\end{array}$ \\
\hline 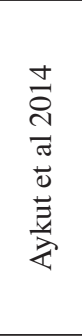 & $\mathrm{RCT}$ & $\begin{array}{l}\text { Therapeutic } \\
\text { effect of CPP- } \\
\text { ACP and } \\
\text { fluoridated } \\
\text { toothpaste on } \\
\text { WSLs }\end{array}$ & $\begin{array}{l}60 \text { children } \\
\text { of age } \\
(13 \pm 0.68) \\
\text { with } 60 \\
\text { WSLs }\end{array}$ & $\begin{array}{c}\text { At baseline } \\
\text { and after } 3 \\
\text { months }\end{array}$ & $\begin{array}{c}\text { The } \\
\text { toothpaste of } \\
1450 \text { ppm F }\end{array}$ & $\begin{array}{c}\text { Lesions were } \\
\text { Recorded using } \\
\text { DIAGNOdent } \\
\text { device }\end{array}$ & $\begin{array}{c}\text { No statistical } \\
\text { significant in } \\
\text { reduction of WSLs } \\
\text { in the test group } \\
\text { and a statistically } \\
\text { significant increase } \\
\text { in scores of WSLs in } \\
\text { control group }\end{array}$ \\
\hline
\end{tabular}




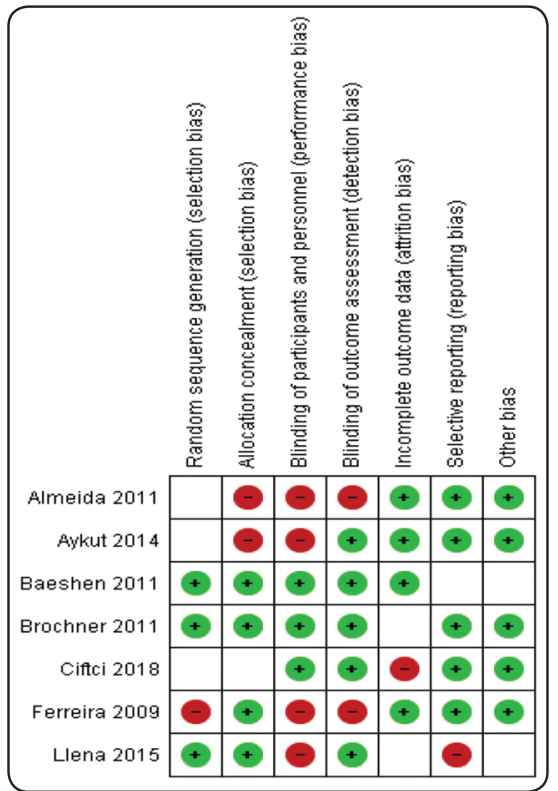

Fig. (1) Presentation of the risk of bias assessments for the studies included in the review

\section{DISCUSSION}

A relatively large number (2455) of publications resulted from the initial literature search on remineralizing agents; however, a deep assessment of the results recorded 29 articles that were inspected in details. Finally, this systematic review selected seven articles.

It may be considered slightly strange that the majority of the evidence on remineralization studies arises from orthodontic patients who are considered a selective group of people undergoing specialized dental care and not mimic the general population. Despite the small specificity of the target group for the included studies, the results shouldn't be ignored 7 as a meta-analysis of 14 studies had demonstrated that the WSLs incidence and prevalence rates were 45.8 and $68.4 \%$.during the orthodontic treatment ${ }^{21}$.

White spot lesions (WSLs) can naturally remineralize by taking minerals from the saliva without the need for any treatment, but this approach had a little effect on deeper lesions structure ${ }^{22,23}$. Enaia et al..$^{24}$ showed that $57.1 \%$ of WSLs improved,
$26.2 \%$ remained the same, and $16.7 \%$ became worse after a 1-year follow-up without any treatment.

WSL remineralization by a fluoride varnish can assist in the improvement of oral hygiene with fluoridated dentifrices. The favorable combination of fluoride and oral hygiene in reducing WSL wouldn't, therefore, be ignored, as the success of fluoride therapy relies on children's incentive to improve oral hygiene ${ }^{25}$.

Three of the included studies $3,11,15$ in this systematic review reported that $\mathrm{CPP}-\mathrm{ACP}$ offers a benefit in terms of reduction of white spot lesions in children and young adolescents similar or even more beneficial (CPP-ACFP) than standard fluoride. Therefore, it would be from wise to recommend CPP-ACP and CPP-ACFP for prevention of these lesions.

Treatment with CPP-ACFP seemed to reduce the severity of caries lesion faster than treatment with CCP-ACP. This improved rate of remineralization may be attributed to the presence of calcium, phosphate and fluoride ions in unstabilized form, which will simply form fluoroapatite. In the lack of CPP, this reaction is weakened by prompt development of calcium phosphate phases ${ }^{26}$, but when stabilized by CPP, these ions spread down into the deeper enamel layers ${ }^{27}$. In addition, some studies found that CPP-ACFP solutions could have an advanced remineralization capacity than CPP $\mathrm{ACP}$ at acidity levels beneath $\mathrm{pH} 5.5$, suggesting its function in highly acidic environments ${ }^{28}$.

The results confirm that CPP - ACFP is superior to both $\mathrm{CPP}$ - ACP and fluoride varnishes in the instant to very short periods after the beginning of treatment ${ }^{11}$.

Nevertheless, because of parental safety concerns, the fluoride-free CPP - ACP appears to be a worthy substitute to lesion reversion in patient groups that are unwilling to use fluoride products. It was reported that $\mathrm{CPP}$ - ACP has the potential 
to enhance remineralization ${ }^{29-33}$ as it maintains calcium and phosphate at a supersaturated state on the enamel surface compared to that in saliva, thus decreasing demineralization and enhancing enamel remineralization ${ }^{34}$.

The children used the CPP - ACP paste directly after a routine fluoridated toothpaste reported that fluoride tends to interfere with the ACP component of the casein complex and precipitate as calcium fluoride resulting in ineffectiveness of both inorganic components ${ }^{35}$. But this could only happen if there is massive fluoride, as there is also a fluoride containing CPP-ACP as shown by Reynolds ${ }^{36}$ who observed that toothpaste containing $2 \% \mathrm{CPP}$-ACP plus 1100 ppm $F$ was higher to all other mouth rinse and dentifrice constructions containing CPP-ACP and fluoride. Controversially, in a study by Beerens et al. $2010{ }^{16}$, which evaluated the effects of CPP - ACPF paste on the remineralization of enamel WSLs, it was reported that there were no variances between the CPP - ACFP and the free fluoride paste in the remineralization of enamel.

Two of the included studies ${ }^{2,6}$ comparing different forms of fluoride-containing $\mathrm{CaF} 2$ with the standard fluoride $\mathrm{NaF}$. They also found that there is no significant difference between these forms as regarding the reduction of initial caries. WSL remineralization can be primarily clarified by the rise in oral $\mathrm{CaF} 2$ reservoirs after fluoride varnish applications and later the solubilization of these reservoirs at low $\mathrm{pH}$ release fluoride ions ${ }^{25}$.

There is evidence that $\mathrm{NaF}$ varnishes effectively increase fluoride absorption and reduce enamel mineral loss under various circumstances ${ }^{37,38}$. Even though the $\mathrm{CaF} 2$ formula may extend the occurrence of fluoride in the oral cavity due to an increase in calcium binding sites ${ }^{39}$.

Of course, one valuable aspect of the $\mathrm{CaF} 2$ varnish is the enhancement of cost-benefit ratio in caries control programs since this product is about 10 times less costly than the $\mathrm{NaF}$ and other comparable fluoridated varnishes ${ }^{6}$.
The only two studies reported with a significant reduction of WSL than standard fluoride were Baschen et al. ${ }^{19}$ who showed the significant effect of fluoridated Miswak and Cefitci et al. ${ }^{4}$ who reported the significant effect of resin infiltrate.

This effect is related mainly to the rapid fluoride release from Miswak, as the remineralizing effect of non-fluoridated Miswak was much smaller ${ }^{40,41}$. The bristle-containing fluoride easily reaches the teeth's buccal surfaces. An additional advantage of using fluoridated Miswak is no requisite for the post-brushing water rinsing; water rinsing has been found to have a deleterious effect on the retention of oral fluoride ${ }^{42}$.

Munoz et al. ${ }^{43}$ reported that resin infiltrate penetrates into active decay lesions when compared with inactive lesions, which is caused by the more porous and thinner surface layer of active lesions. Resin infiltrates block further diffusion of the bacteria by creating barriers and stops lesion development allowing spontaneous remineralization from the saliva ${ }^{4}$.

Meta-analysis couldn't be done due to varied protocols of study designs and different outcome measures in this group of studies. Clearly, more randomized longer-term trials are required.

\section{CONCLUSION}

The findings of this systematic review raise the attention to different remineralizing agents over the standard fluoride for the prevention of early enamel caries. With regards to the use of CPP-ACP and CPP-ACFP for regression of WSLs, there is a direction toward the advantages for their use but the quality of the evidence is limited. On the other hand, there is a significant effect of resin infiltration and fluoridated Miswak over the standard fluoride in the prevention of WSLs. Future well-conducted RCTs considering long-term follow-up periods is needed to establish the best clinical practice. 


\section{Abbreviations}

WSLs: White spot lesions

CPP-ACP: casein phosphopeptide-amorphous calcium phosphate.

CPP-ACFP: Casein phosphopeptide-amorphous calcium fluoride phosphates.

RCT: Randomized clinical trials.

$\mathrm{NaF}$ : Sodium fluoride.

$\mathrm{CaF}$ 2: calcium fluoride.

\section{No conflict of interest}

\section{No funding.}

\section{REFERENCES}

1. Yin $\mathrm{W}, \mathrm{Hu} \mathrm{D}, \mathrm{Li} \mathrm{X}$, et al. The anti-caries efficacy of a dentifrice containing $1.5 \%$ arginine and $1450 \mathrm{ppm}$ fluoride as sodium monofluorophosphate assessed using quantitative light-induced fluorescence (QLF). J Dent. 2013;41: S22-8.

2. Almeida MQd, Costa OXI, Ferreira JMS, et al. Therapeutic potential of Brazilian fluoride varnishes: an in vivo study. Braz Dent J. 2011;22:193-7.

3. Aykut-Yetkiner A, Kara N, Ateş M, et al. Does casein phosphopeptide amorphous calcium phosphate provide remineralization on white spot lesions and inhibition of Streptococcus mutans?. J Clin Pediatr Dent. 2014; 38:302-6.

4. Çiftçi Z, Hanimeli S, Karayilmaz H, et al. The efficacy of resin infiltrate on the treatment of white spot lesions and developmental opacities. Niger J Clin Pract. 2018;21:1444-9.

5. Singh S, Singh SP, Goyal A, et al. Effects of various remineralizing agents on the outcome of post-orthodontic white spot lesions (WSLs): a clinical trial. Prog Orthod. 2016;17:25

6. Ferreira JMS, Aragão AKR, Rosa ADB, et al. Therapeutic effect of two fluoride varnishes on white spot lesions: a randomized clinical trial. Braz Oral Res. 2009;23:446-51.

7. Raphael S, Blinkhorn A. Is there a place for Tooth Mousse ${ }^{\circledR}$ in the prevention and treatment of early dental caries? A systematic review. BMC Oral Health. 2015;15:113.
8. Zohoori F, Maguire A. Are there good reasons for fluoride labeling of food and drink? Br Dent J. 2018;224:215-7.

9. Guclu ZA, Alacam A, Coleman NJ. A 12-week assessment of the treatment of white spot lesions with CPP-ACP pastes and/or fluoride varnish. Biomed Res Int. 2016.

10. Taha AA, Patel MP, Hill RG, et al. The effect of bioactive glasses on enamel remineralization: A systematic review. J Dent. 2017;67:9-17.

11. Llena C, Leyda A, Forner L. CPP-ACP and CPP-ACFP versus fluoride varnish in remineralisation of early caries lesions. A prospective study. Eur J Paediatr Dent. 2015;16:181-6.

12. Philip N. State of the art enamel remineralization systems: the next frontier in caries management. Caries Res. 2019;53:284-95

13. Andersson A, Sköld-Larsson K, Haligren A, et al. Effect of a Dental Cream Containing Amorphous Calcium Phosphate Complexes on White Spot Lesion Regression Assessed by Laser Fluorescence. Oral Health Prev Dent. 2007;5: 229-33.

14. Bailey D, Adams G, Tsao C, et al. Regression of postorthodontic lesions by a remineralizing cream. J. Dent. Res. 2009;88:1148-53.

15. Bröchner A, Christensen C, Kristensen B, et al. Treatment of post-orthodontic white spot lesions with casein phosphopeptide-stabilized amorphous calcium phosphate. Clin Oral Investig. 2011;15:369-73.

16. Beerens M, Van Der Veen M, Van Beek H, et al. Effects of casein phosphopeptide-amorphous calcium fluoride phosphate paste on white spot lesions and dental plaque after orthodontic treatment: a 3-month follow-up. Eur. J. Oral Sci.. 2010;118:610-17.

17. Huang GJ, Roloff-Chiang B, Mills BE, et al. Effectiveness of MI Paste Plus and PreviDent fluoride varnish for treatment of white spot lesions: a randomized controlled trial. Am J Orthod Dentofacial Orthop. 2013;143:31-41.

18. Abdullah Z, John J. Minimally Invasive Treatment of White Spot Lesions--A Systematic Review. Oral Health Prev Dent. 2016;14:197-205.

19. Baeshen HA, Lingström P, Birkhed D. Effect of fluoridated chewing sticks (Miswaks) on white spot lesions in postorthodontic patients. Am J Orthod Dentofacial Orthop. 2011;140:291-7. 
20. Higgins J, Green S. Cochrane Handbook for Systematic Reviews of Interventions Version 5.1. 0 [updated March 2011]. The Cochrane Collaboration, 2011. Accessed August. 2011;29.

21. Sundararaj D, Venkatachalapathy S, Tandon A, et al. Critical evaluation of incidence and prevalence of white spot lesions during fixed orthodontic appliance treatment: A meta-analysis. J Int Soc Prev Community Dent. 2015; $5: 433$.

22. Øgaard B, Rølla G, Arends J, et al. Orthodontic appliances and enamel demineralization Part 2. Prevention and treatment of lesions. Am J Orthod Dentofacial Orthop. 1988; 94:123-8.

23. Cochrane N, Cai F, Huq N, et al. New approaches to enhanced remineralization of tooth enamel. Journal of dental research. 2010;89:1187-97.

24. Enaia M, Bock N, Ruf S. White-spot lesions during multibracket appliance treatment: a challenge for clinical excellence. Am J Orthod Dentofacial Orthop. 2011;140:e17-24.

25. Ferreira JMS, Silva MFA, Oliveira AFB, et al. Evaluation of different methods for monitoring incipient carious lesions in smooth surfaces under fluoride varnish therapy. Int J Paediatr Dent. 2008;18:300-5.

26. Selwitz RH, Ismail AI, Pitts NB. Dental caries. The Lancet. 2007;369:51-9.

27. Reynolds E, Cai F, Cochrane N, et al. Fluoride and casein phosphopeptide-amorphous calcium phosphate. J Dent. Res. 2008;87:344-8.

28. Cochrane N, Saranathan S, Cai F, et al. Enamel subsurface lesion remineralisation with casein phosphopeptide stabilized solutions of calcium, phosphate, and fluoride. Caries Research. 2008;42:88-97.

29. Cai F, Shen P, Morgan M, et al. Remineralization of enamel subsurface lesions in situ by sugar-free lozenges containing casein phosphopeptide-amorphous calcium phosphate. Australian Dental Journal. 2003;48:240-3.

30. Reynolds E. Remineralization of enamel subsurface lesions by casein phosphopeptide-stabilized calcium phosphate solutions. J Dent. Res. 1997;76:1587-95.

31. Reynolds EC. Anticariogenic complexes of amorphous calcium phosphate stabilized by casein phosphopeptides: a review. Spec Care Dentist. 1998;18:8-16.
32. Reynolds E, Cai F, Shen P, et al. Retention in plaque and remineralization of enamel lesions by various forms of calcium in a mouthrinse or sugar-free chewing gum. J Dent Res. 2003;82:206-11.

33. Shen P, Cai F, Nowicki A, et al. Remineralization of enamel subsurface lesions by sugar-free chewing gum containing casein phosphopeptide-amorphous calcium phosphate. J Dent Res. 2001;80:2066-70.

34. Reynolds E, Cain C, Webber E, et al. Anticariogenicity of calcium phosphate complexes of tryptic casein phosphopeptides in the rat. J Dent Res. 1995;74:1272-79.

35. Azarpazhooh A, Limeback H. Clinical efficacy of casein derivatives: a systematic review of the literature. J Am Dent Assoc. 2008;139:915-24.

36. Reynolds EC. Calcium phosphate-based remineralization systems: scientific evidence? Aust Dent J. 2008; 53:268-73.

37. Attin T, Lennon A, Yakin M, et al. Deposition of fluoride on enamel surfaces released from varnishes is limited to vicinity of fluoridation site. Clin Oral Investig. 2007;11:83.

38. Vieira A, Jager D, Ruben J, et al. Inhibition of erosive wear by fluoride varnish. Caries Research. 2007;41:61-7.

39. Delbem ACB, Brighenti FL, Oliveira FAL, et al. In vitro assessment of an experimental coat applied over fluoride varnishes. J Appl Oral Sci. 2009;17:280-3.

40. Baeshen H, Kjellberg H, Lingström P, et al. Uptake and release of fluoride from fluoride-impregnated chewing sticks (miswaks) in vitro and in vivo. Caries research. 2008;42:363-8.

41. Baeshen H, Birkhed D. Release of fluoride from fresh and old NaF-impregnated chewing sticks (Miswaks) in vitro and oral retention in vivo. Oral Health Prev Dent. 2010;8:93-9.

42. Nordström A, Birkhed D. Fluoride retention in proximal plaque and saliva using two $\mathrm{NaF}$ dentifrices containing 5,000 and 1,450 ppm F with and without water rinsing. Caries research. 2009;43:64-9.

43. Muñoz MA, Arana-Gordillo LA, Gomes GM, et al. Alternative esthetic management of fluorosis and hypoplasia stains: blending effect obtained with resin infiltration techniques. J Esthet Restor Dent. 2013;25:32-9. 